\title{
Coping with Food Insecurity in Rural South Africa: The Case of Jozini, KwaZulu-Natal
}

\author{
Mjabuliseni SC Ngidi \\ Sheryl L Hendriks
}

\author{
DST/NRF Centre of Excellence in Food Security; Institute for Food, \\ Nutrition and Well-being and Department of Agricultural Economics, \\ Agricultural Extension and Rural Development, University of Pretoria, South Africa \\ Email: Sheryl.hendriks@up.ac.za
}

\section{Doi:10.5901/mjss.2014.v5n25p278}

\section{Abstract}

This study set out to determine the extent of hunger and determine how frequently the households of members of an irrigation scheme in the Jozini area of KwaZulu-Natal, South Africa adopted precautionary strategies with regard to food security compared to non-scheme households from the same community. A questionnaire and Focus Group Discussions (FGDs) were used to collect qualitative and quantitative data from 69 irrigation scheme households and an equal number of sampled nonscheme households in the winter of 2013. The study compared the frequency of reported hunger and Coping Strategies Index (CSI) scores. Many households experienced hunger in January and June when children return to school after vacations. Relying on less preferred or inexpensive foods was the most commonly employed strategy, practiced by $88 \%$ of the households. Feeding working members at the expense of the non-working was the least commonly practiced strategy $(21 \%$ of the households). A range of coping strategies were employed, especially during the months of higher incidences of reported hunger. No significant differences were observed between irrigation scheme and non-irrigation scheme households regarding CSI scores. Households in this rural location need to be encouraged to engage more actively in home production. Extension services need to assist in planning these gardens to provide food in months when hunger is widespread. Assistance with savings and household budgeting are essential to help households anticipate and plan for months of inadequate income and high expenditure demands.

Keywords: Food security, coping strategies, hunger and scheme

\section{Introduction}

South Africa is reportedly nationally food secure but relatively high levels of household and individual food insecurity exist (BFAP, 2013; Hendriks, 2014). Stats SA (2014) reports that $17 \%$ of households in South Africa and $20.9 \%$ in the KwaZulu-Natal province struggle to access food. In 2013 , about $11.4 \%$ and $34.4 \%$ of households reported experiencing hunger in South Africa and KwaZulu-Natal province, respectively. More than $6 \%$ of South African households and $4 \%$ of the KwaZulu-Natal households experience severe inadequate food access situations as measured by questions relating to food consumption practices (Stats SA, 2014). Food security is only achieved when all members of a household consume adequate food to meet their individual dietary needs on a continual basis (FAO, 1996). Sound nutrition is essential for productivity and health. Households adopt precautionary measures when faced with food insecurity (Barrett, 2010).

A high proportion of South Africa's rural households face the risk of experiencing food shortages and adopting coping strategies that could negatively affect their long-term food security situation. Understanding the experience of household food insecurity is essential for improved measurement and assessment of nutritional and social consequences and the design of more appropriate interventions to address the issues and mitigate food insecurity (Norhasmah et al., 2010). The objective of this study was to determine the extent of hunger and the precautionary measures adopted among sample households from an irrigation scheme and non-scheme households from the same community.

\section{Review of Related Literature}

\subsection{The concept of food security}

The concept and definition of food security has changed since introduction of the concept in the early 1940s (CFS, 2012; United Nations, 1975). The most careful redefinition of food security was negotiated through an international consultation in preparation for the World Food Summit in November 1996. The revised definition reflected a wider recognition of the 
complexities of the technical and policy issues associated with food security (Maxwell, 1996), namely that food security exists "when all people, at all times, have physical and economic access to sufficient, safe and nutritious food to meet their dietary needs and food preferences" (FAO, 1996). The 1996 World Food Summit three dimensions of food security include: food availability, accessibility and utilisation (FAO, 1996). Lately it has included stability of supply as a fourth food security dimension (FAO, 2008).

Food availability refers to the supply of food at local, national or international levels (FAO, 1996). Food access refers to the capability of individuals and households to obtain food and addresses the issues of purchasing power and consumption behaviour (FAO, 1996). Food utilisation refers to the biological availability of nutrients for use by the human body (Gross et al. 2000). Sufficient energy and nutrient intake by individuals is the result of good care and feeding practices, safe food preparation and the consumption of diverse foods (FAO, 2008). Food stability refers to the continuous assurance of adequate availability and accessibility of food. Food security is realised if all four dimensions are fulfilled (FAO, 2008). On the whole, the definition of food security implies families and individuals do not need to worry about where their next meal will come from as it rests on food secure households having access to stable sources of food supply or incomes to purchase food for consumption. Food insecurity refers to the lack of food security, which, in extreme cases, results in hunger (Hendriks, 2005). At household level, a household is food insecure if it does not have adequate food to maintain an active and healthy lifestyle for all of its members (Hendriks, 2014).

\subsection{The food security situation in South Africa}

The right to food is entrenched in section 27 of the Constitution of South Africa (RSA, 1996). The Constitution obliges the State to take all necessary steps to meet citizens' basic food needs, including passing legislation to ensure the right to food security. Section 28(1) of the Constitution further ensures children's unconditional right to basic nutrition. South Africa has set an ambitious target of eliminating poverty and inequality by 2030 (National Planning Commission, 2012). The National Development Plan (NDP) makes reference to a number of interventions to be implemented to improve food security. These include expanded irrigation; security of land tenure - especially for women; and social protection including nutrition education (NPC, 2012). The NDP provides a framework to inform the actions required to address pervasive hunger (NPC, 2012). The NDP calls for collaboration between government, private sector and citizens to establish selfreliant local food systems that would ensure universal access and utilization over time (DMPE, 2014).

Food insecurity is a constraint to development in South Africa and the focus of many state development programmes and initiatives (Battersby, 2011). South Africa's food security situation demands serious and urgent attention amidst excessively high unemployment, high inequality and depressed economic growth (Hendriks, 2013). Building on the already existing food security initiatives, the African National Congress (ANC) identified food security as a key focus area in the 2009 General Elections (ANC, 2014) and was included in the national priority outcomes (Medium Term Strategic Framework) (DPME, 2014). Food security in South Africa has to be addressed within the context of various development issues including but not limited to: poverty, increasing fuel and food prices, sources of income, social protection, rural and urban development, changing household structures, land, health, education, water and sanitation (Stats SA, 2014). Despite progressive constitutional rights for citizens and some progress towards clear development targets, the level of food insecurity in South Africa is considerably high (Hendriks, 2013). Currently there are no legislative measures in place to realise the right to food as enshrined in the Constitution (Hendriks, 2014).

South Africa faces serious food security challenges compared to countries with similar income levels such as Angola, Algeria, Brazil, Malaysia, etc. (DPME, 2014). The South African government recognises that food security is a prerequisite for sustained economic growth and poverty reduction (RSA, 2014). In September 2013, the National Policy on Food and Nutrition Security was approved by Cabinet (RSA, 2014). The policy's goal is to ensure the availability, accessibility and affordability of safe and nutritious food at national and household levels through improved nutritional safety nets, nutrition education, alignment of investment in agriculture, market participation of emerging farmers and risk management.

Numerous national programmes for addressing food insecurity have been implemented and include among others (Hendriks 2014; Abdu-Raheem and Worth 2011):

- Agricultural programmes - e.g. household food production and food preservation

- Social services - e.g. social grants

- Public works programmes

- Nutrition - e.g. school feeding scheme and nutrition education and counselling and

- Free health services (particularly for the children under five years of age). 


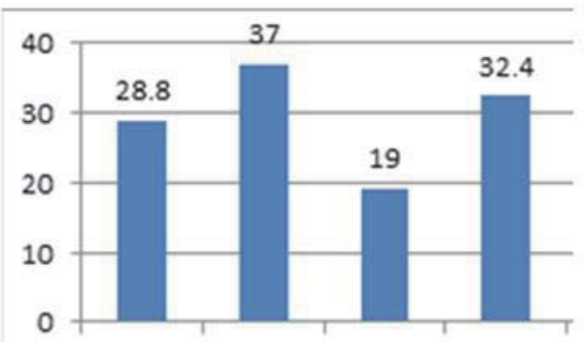

Figure 1: Prevalence of households' experiencing hunger per locality (S.ANHANES-1 2012 data) $(n=6115)$

(Shisana et al., 2013)

Figure 1 shows that prevalence of self-reported hunger in South Africa in 2012 as assessed using a Community Childhood Hunger Identification Project (CCHIP'). More than $30 \%$ of households in the country's rural and urban informal areas reported experiencing hunger in the previous year in 2012 (Shisana et al., 2013). The General Households Survey reported that $11.4 \%$ and $13.4 \%$ of households and individuals respectively in South Africa reported experiencing hunger in the four weeks prior to the General Household Survey of 2013 (Table 1) (Stats SA, 2014).

The results of the GHS (2013) regarding food access, using questions from the Household Food Insecurity Access Scale HFIAS with a 30 day recall period, indicated that the percentage of households reporting limited access to food increased from $21.5 \%$ in 2012 to $23.1 \%$ in 2013 , indicating a $1.6 \%$ increase in the number of households with more limited access to food (Stats SA, 2014). However, the percentage of individuals with limited access to food declined slightly from 26.1\% to 26.0\% between 2012 and 2013 (Table 1). The increase in the number of households with limited access to food clearly indicates that the implementation of the existing food security interventions should be improved (Stats SA, 2014). Table 2 shows the provincial situation with regard to food access and hunger.

Table 1: Hunger and malnutrition situation in South Africa

\begin{tabular}{|l|c|c|c|}
\hline Stats SA GHS 2013 & \multicolumn{2}{|c|}{ SANHANES-1 2012 } \\
\hline Variable & $\%$ & & $\%$ \\
\hline Vulnerability to hunger: households & 11.4 & Stunting & 26.5 \\
\hline Vulnerability to hunger: individuals & 13.4 & Wasting & 2.2 \\
\hline Complex food access: individuals & 26.0 & \multirow{2}{*}{ Under-weight } & \multirow{2}{*}{6.1} \\
\cline { 1 - 2 } Complex food access: households & 23.1 & \\
\hline
\end{tabular}

Sources: Stats SA (2014) and Shisana et al. (2013)

Table 2: Recent food (in)security indicators in South Africa

\begin{tabular}{|l|c|c|c|c|c|c|c|c|c|c|}
\hline & \multicolumn{9}{|c|}{ Province of South Africa } & South Africa \\
\hline Stats SA GHS 2013 data & EC & FS & GP & KZN & LP & MP & NC & NW & WC & RSA \\
\hline Food access severely inadequate & 7.0 & 5.4 & 4.7 & 4.0 & 1.7 & 8.8 & 9.6 & 14.7 & 8.3 & 6.1 \\
\hline Food access inadequate & 22.4 & 21.1 & 13.0 & 20.9 & 7.0 & 20.7 & 21.0 & 22.6 & 15.0 & 17.0 \\
\hline Food access adequate & 70.6 & 73.5 & 82.3 & 75.2 & 91.3 & 70.6 & 69.3 & 62.7 & 76.8 & 76.9 \\
\hline & & & & & & & & & & \\
\hline SANHANES-1 2012 data & EC & FS & GP & KZN & LP & MP & NC & NW & WC & RSA \\
\hline Prevalence of the experience of hunger & 36.2 & 28.8 & 19.2 & 28.3 & 30.8 & 29.5 & 20.7 & 29.5 & 16.4 & 26.0 \\
\hline Household experience of hunger & 32.4 & 31.9 & 24.8 & 34.4 & 27.3 & 15.5 & 22.8 & 30.0 & 25.6 & 28.3 \\
\hline Food secure & 31.4 & 39.3 & 56.0 & 37.3 & 41.9 & 55.0 & 56.5 & 40.4 & 57.9 & 45.6 \\
\hline
\end{tabular}

Sources: Stats SA (2014) and Shisana et al. (2013)

1 The CCHIP index is used internationally for assessing hunger and validated. The CCHIP index is based on eight occurrence questions that represent a generally increasing level of severity of food insecurity (access) and that are related to whether adults and/or children are affected by food shortages, perceived food insufficiency or altered food intake due to constrained economic resources within the household. (Shisana et al., 2013). 
Although self-reported experiences of hunger have dropped since 1999, much can still be done to improve the food security situation in country (Table 3). The findings from four national surveys (using the CCHIP index as proxy for food security) indicated that the proportion of food insecure households halved from 1999 to 2008, reducing from 52.3\% to $25.9 \%$, while the proportion of households at risk of food insecurity ranged from $23.0 \%$ and $27.9 \%$ between 1999 and 2005 (Labadarios et al., 2011; Labadarios 2008). However, the data from SANHANED-1 (Shisana et al., 2013) and GHS 2013 suggest no improvement since 2008.

Table 3: Trends in food security status in South Africa: 1999-2012

\begin{tabular}{|l|c|c|c|c|}
\hline Variable & NFCS & NFCS & SASAS & SANHANES-1, \\
& $\mathbf{1 9 9 9}$ & $\mathbf{2 0 0 5}$ & $\mathbf{2 0 0 8}$ & $\mathbf{2 0 1 2}$ \\
\hline & $\mathrm{n}=2735$ & $\mathrm{n}=2413$ & $\mathrm{n}=1150$ & $\mathrm{n}=6306$ \\
\hline & $\%$ & $\%$ & $\%$ & $\%$ \\
\hline Food secure & 25 & 19.8 & 48 & 45.6 \\
\hline At risk of hunger & 23 & 27.9 & 25 & 28.3 \\
\hline Experiencing hunger & 52.3 & 52 & 25.9 & 26.0 \\
\hline
\end{tabular}

Source: Shisana et al. (2013)

Nationally, $26 \%$ of boys and $25 \%$ of girls aged 1-3 years old were stunted in 2012, an increase over the 2005 NFCS data (Shisana et al,. 2013). There is also a growing obesity problem in children aged 2 to 5 years, with $18.9 \%$ of girls overweight and $4.9 \%$ obese, and $17.5 \%$ of boys overweight and $4.4 \%$ obese (Shisana et al., 2013). This is indicative of poor diet quality.

\section{Food Insecurity in the KwaZulu-Natal Province}

The KwaZulu-Natal (KZN) province is a home to 10457 million people (Stats SA, 2014). Although agricultural support, social grants and school feeding programmes have reportedly improved dietary diversity and improved the intakes of children in the province (D'Haese at al., 2013,), hunger and food insecurity are serious challenges facing rural households in the province (Faber et al., 2011). As indicated in Table 2 above, while $37.3 \%$ of the households in the province were food secure, SANHANES-1 (2012) data showed, using CCHIP, that $28.3 \%$ and $34.4 \%$ of the households in the province experienced hunger and at risk of hunger, respectively. Thirty-one per cent of KZN households reported not having enough money to buy food and or clothes in the SANHANES-1 survey of 2012 (Shisana et al., 2013). Among children under 15 years of age, $13.5 \%$ of boys and $14.4 \%$ of girls were stunted, wasting for boys of the same age group is $2.4 \%$ and underweight for both boys and girls of these under 15 years is 3.4\% and 1.5\%, respectively in 2012 (Shisana et al., 2013).

\subsection{Household food insecurity coping strategies and CSI}

Households pursue various precautionary (coping) measures to avoid hunger and starvation (Barrett, 2010; Maxwell et al., 2003). Households attempt to limit the short-term effects of food shortages through progressive stages (Maxwell and Caldwell 2008). Initial responses to food shortages include dietary adjustments (eating less preferred foods or reducing portion sizes). Such consumption coping strategies can include:

- Households may change their diet. For example, households might switch from consuming preferred foods to cheaper and or less preferred substitutes.

- The household can attempt to increase their food supplies using short-term strategies that are not suitable over a long period. Typical borrowing or purchasing on credit. More examples are begging or consuming wild foods, immature crops, or even seed stocks.

- If the available food is still inadequate to meet needs, households can try to reduce the number of people they have to feed by sending some of them elsewhere (for example, sending kids to the neighbour house when those neighbours are eating)

- Most common, households can attempt to manage the shortfall by rationing the food available to the household (cutting certain household members over others, or skipping whole days without eating) (Maxwell and Caldwell, 2008). 
These are usually reversible strategies that do not generally damage longer-term livelihood prospects (van der Kam, 2001). Should a food shortage materialise, households may sell off non-productive assets. This could threaten future livelihood sustainability or prospects. The sale of productive assets typically follows if the crisis endures or deepens (Maxwell and Caldwell, 2008). These are erosive strategies that are not as easily reversed (Corbett, 1988). The most extreme strategies include dissolving a household or migration (Maxwell and Caldwell, 2008).

Table 4 presents a summary of studies conducted in the KwaZulu-Natal province regarding the precautionary practices households apply when faced with food insecurity during the summer and winter month(s). Household food insecurity studies conducted in KwaZulu-Natal have generally based survey questions on a set of strategies provided by Maxwell et al. (2003). The application of these strategies is not uniform across communities in the province. Shisanya and Hendriks (2011) and Ngidi (2007) found that crop production did not supply households year-round, leading to food shortages in the Maphapheteni area just north of Durban. Mjonono (2008) concluded that food insecurity increased the frequency and severity of application of coping strategies employed by the households in the Embo study area near Durban. Nyakurimwa (2011) found that households adopted extreme strategies including migration and engagement in erosive livelihood strategies when faced with food shortages in Ophansi village of ward three in Jozini.

Table 4: Summary of coping strategies study findings for KwaZulu-Natal

\begin{tabular}{|l|l|l|l|l|l|}
\hline Study & $\begin{array}{l}\text { Sample } \\
\text { size }\end{array}$ & Season & Method & Analytical tools & Findings \\
\hline $\begin{array}{l}\text { Shisanya and Hendriks } \\
\text { (2011) in } \\
\text { Maphephetheni uplands } \\
\text { (2006) }\end{array}$ & $\begin{array}{l}53 \\
\text { households }\end{array}$ & Winter & $\begin{array}{l}\text { Household Food Insecurity } \\
\text { Access Scale (HFIAS) } \\
\text { questionnaire }\end{array}$ & $\begin{array}{l}\text { HFIAS, Spearman's } \\
\text { correlation \& descriptive } \\
\text { statistics }\end{array}$ & $\begin{array}{l}\text { Ate smaller meals than they needed } \\
\text { (83\% of the households) } \\
\text { Ate fewer meals in a day (91\% of the } \\
\text { households) }\end{array}$ \\
\hline $\begin{array}{l}\text { Nyakurimwa (2011) at } \\
\text { Jozini Ophansi village }\end{array}$ & $\begin{array}{l}44 \\
\text { participants }\end{array}$ & Summer & $\begin{array}{l}\text { Participatory Rural Appraisal } \\
\text { (PRA) techniques through a four- } \\
\text { day workshop, supplemented } \\
\text { with stakeholder interviews } \\
\text { Focus group discussions }\end{array}$ & $\begin{array}{l}\text { Historical timeline, seasonal } \\
\text { calendar, focus group } \\
\text { discussions, transect walk, } \\
\text { problem tree analysis }\end{array}$ & $\begin{array}{l}\text { Hunger was commonly associated with } \\
\text { "not eating enough" } \\
\text { The choices included migration to urban } \\
\text { areas in search of employment, women } \\
\text { resorting to sex work. }\end{array}$ \\
\hline $\begin{array}{l}\text { Mjonono (2008) at } \\
\text { Umbumbulu (2006) }\end{array}$ & $\begin{array}{l}200 \\
\text { households }\end{array}$ & Summer & Structured questionnaire & $\begin{array}{l}\text { CSI, descriptive statistics \& } \\
\text { frequencies }\end{array}$ & $\begin{array}{l}\text { Most practiced strategy (67\% of } \\
\text { households) was consuming seed stock } \\
\text { held for next season } \\
\text { Selling assets and borrowing money } \\
\text { from stokvel were the most used income } \\
\text { shock strategies (both used by 52.5\% of } \\
\text { households) }\end{array}$ \\
\hline $\begin{array}{l}\text { Ngidi (2007) at } \\
\text { Maphephetheni (2005) } \\
\text { and Umbumbulu (2006) }\end{array}$ & $\begin{array}{l}268 \\
\text { households }\end{array}$ & Summer & Structured questionnaire & $\begin{array}{l}\text { CSI, descriptive and } \\
\text { spearman correlations }\end{array}$ & $\begin{array}{l}\text { The most used strategy at } \\
\text { Maphephetheni and Umbumbul was } \\
\text { relying on less preferred foods, practiced } \\
\text { by 91\% and 61\% of the households, } \\
\text { respectively. }\end{array}$ \\
\hline
\end{tabular}

\section{Methodological Approach}

\subsection{Survey site: Jozini Municipality}

Jozini is a rural Municipality situated in the Northern KwaZulu-Natal. The area borders Swaziland and Mozambique. Jozini Municipality covers 32\% (3057 square kilometres) of the total area of 13859 square kilometres of uMkhanyakude District Municipality. The district has a scattered rural population of about 625, 846 people (IDP, 2014). Jozini Municipality includes six towns (IDP, 2013). Most of the area is rural and associated with a lack of development, poverty and poor service provision (IDP, 2013). Jozini has an estimated number of households of about 38 991, of that $13806 \mathrm{HHs}$ still do not have access to water (35\%). Ninety per cent of the population earns less than R1 600 per capita per month (IDP, 2013). Approximately $49 \%$ of the population do not earn incomes, which contributes to the cycle of poverty found in the area (IDP, 2013). The large area of Jozini jurisdiction falls under the ownership of Ingonyama Trust with communal tenure arrangements. Some areas are privately owned by individuals and some owned by State (IDP, 2013).

\subsection{Site and sample selection, data collection and analysis}

A survey ( $n=138$ ) was conducted in June 2013 (winter) as part of a multi-purpose study to assess current rain-fed and irrigated production of food crops and its potential to meet all year round nutritional requirements of rural poor people in 
South Africa (WRC, 2013) and develop a food security information system as part of a second research programme.

The site at Jozini was selected through a multi-stage sampling process. A review of socioeconomic indicators was conducted to identify the poorest districts in the province. Within the identified districts, the poorest local municipalities were identified using the Heath Systems Trust Deprivation Index (Day et al., 2011). The index is a measure of relative deprivation of populations derived from a set of demographic and socio-economic variables obtained from national survey data. Although not directly a food security indicator, many of the variables included are also indicators of food insecurity and poverty.

The uMkhanyakude District showed the highest level of deprivation and child under-nutrition from available data at the time of the sampling (Day et al., 2011). Therefore, this district was selected for the study in KwaZulu-Natal. The next stage of sampling was identification of the local municipality with the highest level of deprivation and poverty. While the local municipality with the highest proportion of the population that reported experiencing hunger in this district (1999 and 2005 National Food Consumption Surveys (Labadarios et al., 2000; 2008)) was Hlabisa, the proportion of households receiving migrant income in Hlabisa was relatively high. As this would affect household livelihoods and possibly be a disincentive to agricultural production, the second most deprived local municipality (Jozini) was selected for the study.

As part of the larger study was interested in understanding the contribution of crop production to food security status, the selection criteria for households was that there was at least one child aged between 24 and 59 months and their care-giver present in the homestead and willing to participate in the study. The list of members of a large irrigation scheme in uMkhanyakude (407 members) was obtained and the households residing in Jozini (89 members) were identified. Initially a random sample of 50 households was selected from this list of 89 members using computerised random number generation. Due to the inclusion criteria of having a young child in the household and unavailability of caregivers, substitution of additional randomly selected members, all 69 available qualifying households were interviewed from the members of the irrigation scheme residing in Jozini.

Due to the settlement pattern, terrain and distance between the households in the rain-fed areas in Jozini, a systematic sampling technique was used to identify every 4th household from a randomly selected starting point in the two wards where the irrigation scheme members lived (Ingwavuma and Ubombo). Where a selected household did not meet the inclusion criteria, the neighbouring homestead was interviewed. An equivalent number of non-scheme households (69) were interviewed.

Quantitative data was collected through household surveys and qualitative data was collected through Focus Group Discussions (FGDs). Enumerators from the communities with at least 12 years of completed education were identified and recruited for the field work. Training of enumerators was carried out in stages. The training focussed on interview skills, anthropometric measurement, and the use of a Samsung tablet as a tool for our data collection. Role plays where used to assist enumerators in practicing conducting the interviews to reduce surveys errors. The questions and terminology were translated into Isizulu - the local language in Jozini area - to ensure survey consistency.

Participation in the FDGs was determined by community member availability. The majority of participants were women. FGD questions focused largely on what people in the community do when they have no access to food or money to buy food. The severity of coping strategies was documented for use in calculating the CSI.

The CSI was used to determine levels of food insecurity (Maxwell and Caldwell, 2008). A standard set of simple questions were adopted from Maxwell et al. (2003) to capture basic consumption-related coping strategies to access food in the month prior to the survey. Households were asked how often each strategy had been used in the past 30 days. The frequency was classified as: everyday, pretty often, once in a while, hardly at all and never. For the purposes of calculating the CSI, the responses everyday, pretty often, once in a while, hardly at all and never were valued as 7, 4.5, $1.5,0.5$ and 0 respectively.

Focus groups ranked the coping strategies in order of severity with numbers 1, 2, 3 and 4 representing the least severe, moderate, severe and most severe coping strategies respectively (Maxwell et al., 2003). The CSI was then calculated through multiplying the frequency of application of a strategy reported and practiced by each household by the severity ranking as determined through focus groups. The CSI score was obtained by summing the scores for specific coping strategies. The data were analyzed using the Statistical Package for the Social Sciences (SPSS version 22.0). Analyses included independent t-test samples and Spearman's correlation to analyse relationships.

\section{Results and Discussion}

The objective of this study was to determine the extent of hunger and determine how frequently households used food consumption coping strategies to mitigate hunger. An overview of the descriptive statistics is presented in Table 5. The minimum household size was one and the maximum was 10 , with a mean of 5.40 . The minimum and maximum age of 
the household heads were 19 and 89 respectively, with a mean of 48.58 years. The level of education of the households' heads ranged from no schooling to 12 years of completed school with post-school diplomas or degrees.

Table 5: Descriptive statistics of the sample $(n=138)$, Jozini 2013

\begin{tabular}{|l|c|c|c|c|c|}
\hline Variable & $\mathbf{N}$ & Minimum & Maximum & Mean & Standard deviation \\
\hline Household size & 138 & 1 & 10 & 5.40 & 2.27 \\
\hline Age of the head & 138 & 19 & 89 & 48.58 & 15.50 \\
\hline Education of the head & 138 & 0 (No schooling) & $>12$ years & & \\
\hline CSI score & 138 & 19 & 176.50 & 63.51 & 40.15 \\
\hline CSI score irrigation scheme members households & 69 & 19 & 167.00 & 69.27 & 41.93 \\
\hline CSI score non- scheme households & 69 & 19 & 176.5 & 57.75 & 37.71 \\
\hline
\end{tabular}

The sample households produced: amadumbe (taro), avocado, beetroot, butternut, banana, cabbage, dry beans, gords, green paper, lettuce, maize, onions, pumpkins, spinach, sweet potatoes, sugar cane and tomatoes in the 2012/2013 growing season. Cabbage was grown by most respondents, on an average of 0.4 ha per farmer. This was followed by maize, which was planted on an average area of 2 ha per farmer. Thirty-one per cent of respondents were involved in poultry farming (chickens), and about 30\% in livestock production (cattle, goats, sheep and pigs). Twenty-two per cent of respondents were involved in grain production. About $15 \%$ of the respondent households were engaged in fruit and vegetable production, while two per cent of the respondents were engaged in commercial crop production of tea, coffee and cotton.

Forty-seven per cent of household heads were subsistence farmers. Forty-four per cent of household heads reported they were unemployed. Only 10 household heads were formally employed, while 12 were unpaid family workers. Twenty-eight respondents from the non-scheme households were unemployed compared to 16 of the irrigation scheme member households. About 38 respondents from the irrigation scheme member households were subsistence farmers compared to only nine from the non-scheme sample. Eleven members were said to be unpaid family workers from the non-scheme households compared to just one from the irrigation scheme member households.

Households were engaged in home, communal and school gardens and plot production on the irrigation scheme. Households belonging to the irrigation scheme farmed on the scheme plots, while non-scheme households were mainly engaged in home garden activities (see Table 6).

Table 6: Participation in food production, Jozini $2013(n=138)$

\begin{tabular}{|l|c|c|c|c|}
\hline \multirow{2}{*}{ Food production engagement } & \multicolumn{2}{|c|}{ Non-scheme households } & \multicolumn{2}{c|}{ Irrigation scheme households } \\
\cline { 2 - 5 } & Frequency $(\mathbf{n = 6 9 )}$ & $\%$ & Frequency $(\mathbf{n}=69)$ & $\%$ \\
\hline Home gardens & 31 & 44.9 & 10 & 14.5 \\
\hline Farm land (communal or private) & 20 & 28.9 & 43 & 63.6 \\
\hline Communal gardens & 0 & 0 & 13 & 18.8 \\
\hline School garden & 2 & 2.9 & 0 & 0 \\
\hline Do not farm & 9 & 13.0 & 1 & 1.4 \\
\hline Total & 69 & 100.0 & 69 & 100.0 \\
\hline
\end{tabular}

Food shortages were reported as common in the second half of each month by members of Focus Group Discussions (FGDs). January, June and July were typically months of hunger. June and July are the winter months when very little was available in gardens and plots in this community. Half the households (both irrigation scheme members and nonscheme members) experienced hunger in January of the previous year, while $18 \%$ of the surveyed households (both irrigating scheme members and non-irrigating scheme members) reported that they experienced hunger in the month of June of the previous year (Figure 2). 


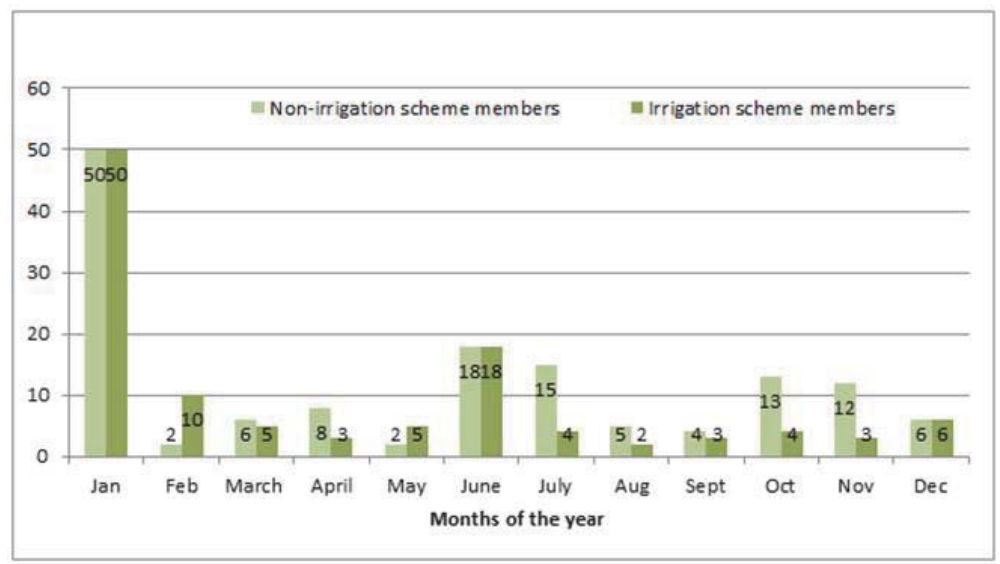

Figure 2: Number of households experiencing hunger over a year, July $2013(n=138)$

Households used various strategies to mitigate the effects of these food shortages (Table 6). As indicated, this study was carried out during the hunger period (winter) and so the strategies adopted reflect practices during this period. Relying on less preferred and or inexpensive foods was the most commonly employed strategy - $88.4 \%$ of the sampled households reporting using this strategy in the past month prior to the survey. This was followed by borrowing food or money for food and begging from friends or relatives for food (each practiced by $85.5 \%$ of the households). The least commonly employed strategy was feeding working members at the expense of the non-working members (practised by only $21.2 \%$ of the households). When comparing irrigation scheme members and non-scheme households, about $86 \%$ of scheme households relied on less preferred or less expensive foods compared to $91 \%$ of the non-scheme households. Feeding working members at the expense of non-working members was the least employed strategy by both irrigation scheme members and non-irrigation scheme members (Table 7). About $71 \%$ of the non-scheme households limited their own food intake for the sake of the children compared to $64 \%$ from the irrigation scheme households.

Table 7: Percentage of households that employed different coping strategies in Jozini, July 2013 ( $n=138)$

\begin{tabular}{|c|c|c|c|c|c|c|}
\hline \multirow[t]{2}{*}{ Coping strategy } & \multicolumn{5}{|c|}{ Households using strategy (\%) } & \multirow[t]{2}{*}{$\begin{array}{c}\text { Categorisation of the } \\
\text { strategy* }\end{array}$} \\
\hline & \multicolumn{2}{|c|}{$\begin{array}{l}\text { Irrigation scheme } \\
\text { members }\end{array}$} & \multicolumn{2}{|c|}{$\begin{array}{c}\text { Non- } \\
\text { scheme } \\
\text { members }\end{array}$} & $\begin{array}{c}\text { All } \\
\text { households }\end{array}$ & \\
\hline & \multicolumn{2}{|c|}{$(n=69)$} & \multicolumn{2}{|c|}{$(n=69)$} & $(n=138)$ & \\
\hline Rely on less preferred or less expensive foods & $\checkmark$ & 85.5 & $\checkmark$ & 91.3 & 88.4 & Dietary change \\
\hline Borrow food/money for food & $\checkmark$ & 84.1 & $\checkmark$ & 87 & 85.5 & \multirow{4}{*}{$\begin{array}{l}\text { Increase short-term } \\
\text { household food } \\
\text { availability }\end{array}$} \\
\hline Purchase food on credit & $\checkmark$ & 52.2 & $\checkmark$ & 34.8 & 43.5 & \\
\hline Gather wild food, hunt or harvest immature crops & $\checkmark$ & 39.7 & $\checkmark$ & 34.3 & 37 & \\
\hline Consume seed stock held for next season & $\checkmark$ & 58.8 & $\checkmark$ & 65.2 & 62 & \\
\hline Limit food portion size at meal times & $\checkmark$ & 79.7 & $\checkmark$ & 81.2 & 80.4 & \multirow{6}{*}{$\begin{array}{l}\text { Rationing or managing } \\
\text { the shortfall strategies }\end{array}$} \\
\hline Limit own intake for children's sake & $\checkmark$ & 63.8 .2 & $\checkmark$ & 71 & 67.4 & \\
\hline Reduce number of meals eaten in a day & $\checkmark$ & 79.7 & $\checkmark$ & 72.5 & 76.1 & \\
\hline Skip whole day without eating & $\checkmark$ & 44.9 & $\checkmark$ & 24.6 & 34.3 & \\
\hline $\begin{array}{l}\text { Feed working members at the expense of non- } \\
\text { working members }\end{array}$ & $\checkmark$ & 37.7 & $\checkmark$ & 4.4 & 21.2 & \\
\hline Ration money to buy street food & $\checkmark$ & 66.2 & $\checkmark$ & 14.7 & 40.4 & \\
\hline Send household members to eat elsewhere & $\checkmark$ & 69.6 & $\checkmark$ & 20.3 & 44.9 & \multirow{3}{*}{$\begin{array}{c}\text { Decrease numbers of } \\
\text { people }\end{array}$} \\
\hline Beg for food from neighbours or relatives & & 81.2 & $\checkmark$ & 79.4 & 80.3 & \\
\hline Rely on help from relatives or friends & $\checkmark$ & 85.5 & $\checkmark$ & 85.5 & 85.5 & \\
\hline
\end{tabular}

$\checkmark=$ Identified as a one of the strategies applied by at least one sample household.

* As per Maxwell and Caldwell's (2008) classification.

Twenty-four per cent of households relied on less preferred or less expensive foods everyday, while about $25 \%, 21 \%$, $19 \%$ reported relying on less preferred or less expensive foods sometimes, hardly, pretty often, respectively. About $12 \%$ 
never used this strategy (Table 8). Very few households employed a strategy of consuming seed stock held for the next season, skipping whole days without eating, feeding working members at the expense of non-working members, sending household members to eat elsewhere, begging for food from neighbours or relatives, everyday (7 days) of the week. About 36\% of the households indicated that they sometimes (1-2 days) relied on help from relatives or friends or begged for food from neighbours or relatives. About $41 \%$ of households sometimes employed borrowed food or money for food. None of the respondent households employed the strategy of rationing money to buy street food seven day per week. However, 5.8\%, 9.5\% and 5.1\% used this strategy pretty often, sometimes and hardly at all, respectively (Table 8).

Table 8: Percentage of households that employed different coping strategies in Jozini, July $2013(n=138)$

\begin{tabular}{|l|c|c|c|c|c|c|}
\hline Coping strategy used by households & \multicolumn{3}{|c|}{ Frequency of application (\%) of the strategy } & \multicolumn{2}{c|}{$\begin{array}{c}\text { Severity of the } \\
\text { strategy* }\end{array}$} \\
\hline & Never & $\begin{array}{c}<1 \\
\text { day }\end{array}$ & $\begin{array}{c}1-2 \\
\text { day }\end{array}$ & $\begin{array}{c}3-6 \\
\text { days }\end{array}$ & $\begin{array}{c}7 \\
\text { days }\end{array}$ & \\
\hline $\begin{array}{l}\text { Feed working members at the expense of non- } \\
\text { working members }\end{array}$ & 78.8 & 5.1 & 9.5 & 5.8 & 0.7 & \\
\hline Ration money to buy street food & 59.6 & 11.0 & 17.6 & 11.8 & 0.0 & \\
\hline Purchase food on credit & 56.6 & 11.6 & 17.4 & 10.1 & 4.3 & 1 \\
\hline Rely on less preferred or less expensive foods & 11.6 & 21.0 & 24.6 & 18.8 & 23.9 & 2 \\
\hline Limit food portion size at meal times & 19.6 & 19.6 & 28.3 & 24.6 & 8.0 & \\
\hline Reduce number of meals eaten in a day & 23.9 & 16.7 & 30.4 & 24.6 & 4.3 & \\
\hline Gather wild food, hunt or harvest immature crops & 63.0 & 8.1 & 14.1 & 13.3 & 1.5 & 2 \\
\hline Send household members to eat elsewhere & 55.1 & 9.4 & 15.9 & 17.4 & 2.2 & 3 \\
\hline Beg for food from neighbours or relatives & 19.7 & 26.3 & 35.8 & 16.1 & 2.2 & 3 \\
\hline Rely on help from relatives or friends & 14.5 & 25.4 & 35.5 & 21.0 & 3.6 & \\
\hline Limit own intake for children's sake & 32.6 & 19.6 & 21.0 & 18.1 & 8.7 & \\
\hline Borrow food/money for food & 14.5 & 20.3 & 41.3 & 18.8 & 5.1 & 3 \\
\hline Consume seed stock held for next season & 38.0 & 16.1 & 21.9 & 23.4 & 0.7 & 4 \\
\hline Skip whole day without eating & 65.7 & 13.1 & 10.2 & 10.2 & 0.7 & 4 \\
\hline
\end{tabular}

1= Least Severe coping strategy, 2= moderately severe strategy, 3= Severe coping strategy and, 4 = Most severe coping strategy. - = strategy reported not to be used in the area as per the knowledge of the focus group. * Severity ranking is as per the perceived view of the community.

The severity ranking of coping strategies was determined through focus group discussions held in July 2013. Of the 14 coping strategies, three were undertaken during the most severe situations (Table 8). The most severe strategies included borrowing food or money to buy food, skipping the whole day without eating and consuming seed stock held for next season. Five coping strategies were undertaken during severe situations. The most commonly employed strategy under the severe strategies was relying on help from friends or relatives for food. Another three strategies were undertaken during moderately severe situations. The mostly commonly used strategy under the moderately severe strategies was relying on less preferred or less expensive foods. Only one strategy was undertaken during least severe situations, suggesting that communities view their hunger period coping strategies as not so good.

Although purchasing food on credit was perceived to be a least severe strategy by the FGDs, this credit can have long-term erosive effects on food security, especially if used frequently. Skipping the entire day without eating food might have a negative effect on the health of households, particularly if that household member is on medication. This means that if these rural households employ this strategy often, households are likely to default on their medication. Five per cent of the households borrowed food every day. The FGD participants viewed borrowing food as great source of shame. This strategy is reportedly a source of conflict in the community when households fail to bring back an identical brand of food borrowed. Table 9 indicates frequency of application of the strategies by irrigation scheme members and nonirrigation scheme households. 
Table 9: Frequency of application of coping strategies, Jozini, July $2013(n=138)$

\begin{tabular}{|c|c|c|c|c|c|}
\hline \multirow[t]{2}{*}{ Irrigation scheme member households } & \multicolumn{5}{|c|}{ Frequency of application (\%) of the strategy } \\
\hline & Never & $<$ iday & 1-2day & 3-6days & 7days \\
\hline Feed working members at the expense of non-working members & 62.3 & 5.8 & 18.8 & 11.6 & 1.4 \\
\hline Ration money to buy street food & 33.8 & 16.2 & 33.8 & 16.2 & 0.0 \\
\hline Purchase food on credit & 47.8 & 10.1 & 21.7 & 14.5 & 5.8 \\
\hline Rely on less preferred or less expensive foods & 14.5 & 30.4 & 30.4 & 21.7 & 2.9 \\
\hline Limit food portion size at meal times & 20.3 & 23.2 & 30.4 & 24.6 & 1.4 \\
\hline Reduce number of meals eaten in a day & 20.3 & 14.5 & 34.8 & 30.4. & 0.0 \\
\hline Gather wild food, hunt or harvest immature crops & 60.3 & 5.9 & 14.7 & 17.6 & 1.5 \\
\hline Send household members to eat elsewhere & 30.4 & 11.6 & 23.2 & 30.4 & 4.3 \\
\hline Beg for food from neighbours or relatives & 18.8 & 24.6 & 33.3 & 18.8 & 4.3 \\
\hline Rely on help from relatives or friends & 14.5 & 31.9 & 31.9 & 18.8 & 2.9 \\
\hline Limit own intake for children's sake & 36.2 & 21.7 & 21.7 & 17.4 & 2.9 \\
\hline Borrow food/money for food & 15.9 & 17.4 & 43.5 & 20.3 & 2.9 \\
\hline Consume seed stock held for next season & 41.2 & 10.3 & 29.4 & 19.1 & 0.0 \\
\hline Skip whole day without eating & 55.9 & 14.7 & 13.2 & 16.2 & 0.0 \\
\hline \multirow[t]{2}{*}{ Non-scheme households } & \multicolumn{5}{|c|}{ Frequency of application (\%) of the strategy } \\
\hline & Never & $<$ iday & 1-2day & 3-6days & 7days \\
\hline Feed working members at the expense of non-working members & 95.6 & 4.4 & 0.0 & 0.0 & 0.0 \\
\hline Ration money to buy street food & 85.3 & 5.9 & 1.5 & 7.4 & 0.0 \\
\hline Purchase food on credit & 65.2 & 13.0 & 13.0 & 5.8 & 2.9 \\
\hline Rely on less preferred or less expensive foods & 8.7 & 11.6 & 18.8 & 15.9 & 44.9 \\
\hline Limit food portion size at meal times & 18.8 & 15.9 & 26.1 & 24.6 & 14.5 \\
\hline Reduce number of meals eaten in a day & 27.5 & 18.8 & 26.1 & 18.8 & 8.7 \\
\hline Gather wild food, hunt or harvest immature crops & 65.7 & 10.4 & 13.4 & 9.0 & 1.5 \\
\hline Send household members to eat elsewhere & 79.7 & 7.2 & 8.7 & 4.3 & 0.0 \\
\hline Beg for food from neighbours or relatives & 20.6 & 27.9 & 38.2 & 13.2 & 0.0 \\
\hline Rely on help from relatives or friends & 14.5 & 18.8 & 39.1 & 23.2 & 4.3 \\
\hline Limit own intake for children's sake & 29.0 & 17.4 & 20.3 & 18.8 & 14.5 \\
\hline Borrow food/money for food & 13.0 & 23.2 & 39.1 & 17.4 & 7.2 \\
\hline Consume seed stock held for next season & 34.8 & 21.7 & 14.5 & 27.5 & 1.4 \\
\hline Skip whole day without eating & 75.4 & 11.6 & 7.2 & 4.3 & 1.4 \\
\hline
\end{tabular}

Consuming less preferred foods was employed everyday by only $2.9 \%$ of the irrigation scheme households compared to $44.9 \%$ of non-scheme households. About $14 \%$ of the non-scheme households limited food portion sizes at meal times and also limited own food intake for the sake children everyday compared $1.4 \%$ and $2.9 \%$ of irrigation scheme households, respectively. While Table 9 indicates that irrigation scheme households did not reduce the number of meals eaten in a day everyday of the week, but $30.4 \%$ and 34.8 of the same households employed the strategy pretty often and sometimes during week. Consuming seed stock set aside for next season was applied pretty often by $27.5 \%$ of the nonscheme households compared to $16.2 \%$ of the irrigation scheme households. This strategy could have a negative effect on the following season's food production - leading to an even greater problem of food insecurity.

The estimated mean CSI scores for irrigation scheme and non-scheme households were 69.27 and 57.75, respectively. On average, irrigation scheme households had relatively higher levels of food insecurity than non-scheme households. However, an independent samples t-test showed that there was no significant difference between the CIS of irrigation scheme households compared to the non-scheme households ( $t=-1.696, p=0.092)$. Results from the Spearman's correlation showed a negative significant relationship between CSI scores and five food insecurity coping strategies, including: eating less preferred or less foods $(p=0.001)$, limiting food portion sizes at meal times $(p=0.037)$, consuming seed stocks set aside for next season $(p=0.034)$, reducing number of meals eaten in a day $(p=0.034)$ and begging from neighbours or relatives for food $(p=0.013)$. The negative relationship between CSI scores and application of coping strategies means if households minimise of the use of these strategies, their CSI scores also reduce. This leads to a better food security situation for the households because as CSI scores decrease, households decrease on the use of these five strategies. 


\section{Conclusion and Recommendations}

This study investigated the extent of hunger and determined how frequently sampled households used food consumption coping strategies to mitigate hunger in Jozini. No significant differences were found between the two groups, but the use of various strategies to buffer hunger and starvation was common. Some of the coping strategies would compromise diet adequacy and quality. Borrowing food from neighbours caused conflict among community members. Coping strategies like feeding working members at the expense of non-working members undermine household unity and stability. However, generally the coping strategies applied were not erosive albeit focus group participants saw the application of some of these strategies as indicative of severe food insecurity.

Although social grants buffer such households from hunger, there are months of the year that households need support to avoid negative consumption reduction practices and reduce the incidence of seasonal hunger. Interventions that seek to help such households save in anticipation of lumpy payments such as school fees, stationery and uniforms in January and June are crucial to ensure year-round food security. More households need to engage in home gardening to increase food availability. Extension services should assist with planning food production to provide food year-round. Food preparation, meal planning and nutrition advice to support home production of fresh produce is also needed.

\section{Acknowledgements}

This article is based on research funded by the South African Water Research Commission (WRC Project No.K5/2172/4), the South African National Research Foundation (Grant numbers CPR20110706000020, 77053 and 80529) and the University of Pretoria's Post-Doctoral Fellowship Programme. The authors accept responsibility for any opinions, findings, conclusions and recommendations contained in this article.

\section{References}

Abdu-Raheem, K.A., \& Worth, S.H. (2011). Household food security in South Africa: Evaluating extension's paradigm relative to the current food security and development goals. South African Journal of Agricultural Extension 39(2), 91-103.

ANC (African National Congress) (2014). Key commitments to move South Africa forward. 2014 Election Manifesto. Marshalltown. http://www.anc.org.za/2014/wp-content/themes/anc/downloads/Manifesto_Booklet.pdf (September 24, 2014).

Barrett, C. B. (2010). Measuring food insecurity. Science, 327, 825. doi: 10.1126/science.1182768.

Battersby, J. (2011). Urban food insecurity in Cape Town, South Africa: An alternative approach to food access. Development Southern Africa 28(4), 545 -561.

BFAP (Bureau for Food and Agricultural Policy) (2012). BFAP baseline: Agricultural outlook 2012-2021. Pretoria: BFAP.

CFS (Committee on World Food Security) (2012). Global strategic framework for food security and nutrition. Rome: CFS.

Corbett, J.E.M. (1988). Famine and household coping strategies. World development 16 (29), 1099-1112.

Day, C., Barron, P., Massyn, N., Padarath, A., English, R. (2012). The District Health Barometer 2010/2011. Health Systems Trust, Durban. http://www.hst.org.za/sites/default/files/DHB\%202010-11lowres.pdf

DPME (Department of Planning, Monitoring and Evaluation) (2014). The Medium-Term Strategic Framework (MTSF) 2014/2015. Department of Performance, Monitoring and Evaluation. Office of the Presidency, Pretoria.

D'Haese, M., Vink, N., Nkunzimana, T., Van Damme, E., Van Rooyen, J., Remaut, A., Staelens, L., \& D'Haese, L. (2013). Improving food security in the rural areas of KwaZulu-Natal province, South Africa: Too little, too slow. Development Southern Africa 30(45), $468-490$.

Grobler, W. (2014). Food insecure household coping strategies: The case of a low income neighbourhood in South Africa. Mediterranean Journal of Social Sciences 5(13), 100-106.

Gross, R., Schoeneberger, H., Pfeifer, H., \& Preuss. H.A. (2000). The four dimensions of food security: Definitions of Food and Nutrition Security. URL: http://www.foodsec.org/DL/course/shortcourseFA/en/pdf/P-01_RG_Concept.pdf (April 10, 2008).

Faber, M., Witten, C., \& Drimie, S. (2011). Community-based agricultural interventions in the context of food and nutrition security in South Africa. S Afr J Clin Nutr 24(1), 21-30.

FAO (Food \& Agriculture Organisation) (2008). An introduction to the basic concepts of food security.EC-FAO Food Security Programme. URL:http://www.foodsec.org/docs/concepts_guide.pdf (July 25, 2010).

FAO (Food \& Agriculture Organisation) (1996). Rome declaration on world food security.World Food Summit.13-17 November. Rome: Food \& Agriculture Organisation.

Hendriks S.L. (2014). Food security in South Africa: Status quo and policy imperatives. Agrekon, 53(2), 1-24.

Hendriks, S.L. (2013). South Africa's national development plan and new growth path: reflections on policy contradictions and implications for food security. Agrekon 52(3), 1-17.

Hendriks, S.L. (2005). The challenges facing empirical estimation of food (in) security in South Africa. Development Southern Africa 22(1), 1-21. 
IDP (Integrated Development Plan) (2014). UMkhanyakude District Municipality. Integrated Development Plan. 3 $3^{\text {rd }}$ generation:2013/2014. Mkhuze, KwaZulu-Natal.

IDP (Integrated Development Plan) (2013). Jozini Local Municipality. 2012/2013 to 2016/2017 Integrated Development Plan. Jozini, KwaZulu-Natal.

Labadarios, D., Mchiza, Z.J.R., Steyn, N.P., Gericke, G., Maunder, E.M.W., Davids, Y.D., \& Parker, W. (2011). Food security in South Africa: a review of national surveys. Bulletin of the World Health Organization 89(12), 891-899.

Labadarios, D., Swart, R., Maunder, E.M.W., Kruger, H.S., Gericke, G.J., Kuzwayo, P.M.N. et al. (2008). Executive summary of the National Food Consumption Survey Fortification Baseline (NFCS-FB-I) SA, 2005. SA J Clin Nutr 21(Suppl. 2), 247-300.

Labadarios, D. (2000). The National Food Consumption Survey (NFCS): children aged 1-9 years, South Africa, 1999. Stellenbosch Directorate. Nutrition Department of Health, National Food Consumption Survey Consortium. Stellenbosch.

Labadarios, D., \& Nel, H.H. (2000). Chapter 4: Anthropometric Status. In: Labadarios, D. (ed.). The National Food Consumption Survey (NFCS): Children aged 1-9 years, South Africa, 1999. The National Food Consumption Survey (NFCS), Stellenbosch.

Maxwell, D., \& Caldwell, R. (2008). The Coping Strategies Index (CSI): A tool for rapid measurement of household food security and impact of food aid programs in humanitarian emergencies. Field methods manual, second edition. http://www.fsnnetwork.org/ sites/default/files/coping_strategies_tool.pdf (February 28, 2014).

Maxwell, D., Watkins, B., Wheeler R., \& Collins G. (2003). The Coping Strategies Index: A tool for rapid measurement of household food security and impact of food aid programs in humanitarian emergencies. CARE and World Food Programme. Rome.

Maxwell, S. (1996). 'Food security: a post-modern perspective.' Food Policy 21 (2), 155-170.

Mjonono, M. (2008). An investigation of household food insecurity coping strategies in Umbumbulu. Masters (Food Security) thesis. African Centre for Food Security, University of KwaZulu-Natal, Pietermaritzburg.

NPC (National Planning Commission) (2012). National Development Plan. Pretoria: National Planning Commission, Office of the Presidency.

Ngidi, M. (2007). Measuring the impact of crop production on household food security in KwaZulu-Natal using Coping Strategies Index (CSI). Masters (Food Security) thesis. African Centre for Food Security, University of KwaZulu-Natal, Pietermaritzburg.

Norhasmah, S., Zalilah, M.S., Mohd Nasir, M.T., Kandiah, M., \& Asnarulkhadi, A.S. (2010). A qualitative study on Coping strategies among women from food insecurity households in Selangor and Negeri Sembilan. Mal J Nutr 16(1), 39-54.

Nyakurimwa, K. (2011). Analysis of local understanding of food insecurity and the socio-economic causes of food insecurity in Ward three of the Jozini Municipality, KwaZulu-Natal. Masters (Food Security) dissertation. African Centre for Food Security, University of KwaZulu-Natal, Pietermaritzburg.

RSA (Republic of South Africa) (2014). National Policy on Food and Nutrition Security. Government Gazette. 590 (37915), 25-44. Republic of South Africa Government Printing Works: Pretoria.

RSA (Republic of South Africa) (1996). The Bill of Rights of the Constitution of the Republic of South African. Pretoria: Government Gazette. (No. 17678), Pretoria.

Shisana, O., Labadarious, D., Rehle, T., Simbayi, L., Zuma, K., Dhansay, A., Reddy, P., Parker, W., Hoosain, E., Naidoo, P., Hongoro, C., Mchiza, Z., Steyn, N.P., Dwane, N., Makoae, M., Maluleke, T., Ramlagan, S., Zungu, N., Evans, M.G., Jacobs, L., Faber, M., \& SANHANES-1 Team. (2013). South African National Health and Nutrition Examination Survey (SANHANES-1). HSRC Press, Cape Town. http://www.hsrc.ac.za/uploads/pageContent/3893/SANHANES-launch\%20edition\%20(online\%20version).pdf_March 03, 2014).

Shisanya, S., \& Hendriks, S.L. (2011). The contribution of community gardens to food security in the Maphephetheni uplands, determined by Household Food Insecurity Access Scale. Development Southern Africa 28(4), 509-526.

Statistics South Africa (Stats SA) (2014). General Household Survey 2013. Statistical release P0318. Stats SA, Pretoria.

United Nations (1975). Report of the World Food Conference. Rome 5-16 November 1974. New York.

Van der Kam, S. (2001). Stage of food insecurity process: Household-level coping mechanisms. URL: http://www.ennonline.net/ fex/10gu21.html-20k-Cached-Similar (March 23, 2012).

WRC (Water Research Commission). (2013). Knowledge Review. WRC. p 255. http://www.wrc.org.za/Lists/Knowledge\%20Hub\%20 Items/Attachments/10473/WRC\%20Knowledge\%20Review\%202012_13\%20KSA4.pdf (September 23, 2013). 